\title{
PENERAPAN METODE ANALISIS VIDEO SOFTWARE TRACKER DALAM PEMBELAJARAN FISIKA KONSEP GERAK JATUH BEBAS UNTUK MENINGKATKAN KETERAMPILAN PROSES SISWA KELAS X SMAN 1 SOOKO MOJOKERTO
}

\author{
${ }^{1)}$ Muhammad Habibbulloh, ${ }^{1)}$ Madlazim \\ ${ }^{1)}$ Jurusan Fisika Universitas Negeri Surabaya.
}

\begin{abstract}
Has been done research for knowing skills process which owned by students after applying method video analysis software Tracker in grade X SMAN 1 Sooko Mojokerto. Purpose of this research was describe enforceability of learning, skills science process which owned students after applying method of video analysis software Tracker, students activity, the response of students, and constraints which faced when learning process. Type of this research is Descriptive Quantitative with design one group pretest posttest, one class were given treatment and replicated one time. From the the results obtained can be concluded that the skill process of students in terms observing, measuring, designing experimenting, interpretationing the data, and communicating after applying method video analysis software Tracker experiencing increases in both quality and quantity. Wherein enforceability of the learning was good, activity students that very good, the response of students that also good, some constraints which emerged moment learning activities has been resolved. By quantity visible from increase in the number students who pass within work on the questions of skills process. In quality is the increase score average each class at the time post test compared the results pre test.
\end{abstract}

Key words: skills process, method video analysis software Tracker.

\begin{abstract}
Abstrak
Telah dilakukan penelitian untuk mengetahui keterampilan proses yang dimiliki siswa setelah menerapkan metode analisis video software Tracker di kelas X SMAN 1 Sooko Mojokerto. Tujuan penelitian ini adalah mendeskripsikan keterlaksanaan pembelajaran, keterampilan proses sains yang dimiliki siswa setelah menerapkan metode analisis video software Tracker, aktivitas siswa, respon siswa, dan kendala yang dihadapi pada saat pembelajaran. Jenis dari penelitian ini adalah Deskriptif Kuantitatif dengan desain one group pretest posttest, satu kelas yang diberi perlakuan dan direplikasi satu kali. Dari hasil yang diperoleh dapat disimpulkan bahwa keterampilan proses siswa dalam hal mengamati, mengukur, merancang eksperimen, interpretasi data, dan berkomunikasi setelah menerapkan metode analisis video software Tracker mengalami kenaikan baik secara kualitas maupun kuantitas. Dimana keterlaksaan pembelajaran yang baik, aktivitas siswa yang sangat baik, respon siswa yang juga baik, beberapa kendala yang muncul saat kegiatan pembelajaran telah dapat diatasi. Secara kuantitas terlihat dari peningkatan jumlah siswa yang tuntas dalam mengerjakan soal keterampilan proses. Secara kualitas adalah peningkatan skor rata-rata tiap kelas pada saat post tes dibandingkan hasil pre tes.
\end{abstract}

Kata kunci: keterampilan proses, metode analisis video software Tracker. 


\section{PENDAHULUAN}

Proses pembelajaran dewasa ini sering hanya mengacu pada hasil pembelajaran. Padahal lebih dari itu, proses untuk mendapatkan hasil tersebut sebenarnya juga merupakan sesuatu yang sangat penting. Hal ini dapat diilustrasikan bahwa selama ini pembelajaran dikatakan berhasil bilamana siswa mampu menyelesaikan soal-soal ulangan atau ujian dengan memperoleh nilai baik. Selain itu, guru telah selesai melaksanakan tugasnya jika semua materi pembelajaran yang terdapat dalam kurikulum sudah tersampaikan kepada siswa. Dengan demikian guru akan merasa bahagia apabila materi pembelajaran telah selesai dan hasil belajar siswa baik. Illustrasi tersebut menunjukkan bahwa pembelajaran masih berorientasi pada hasil dan substansi pembelajaran, sedangkan proses masih terabaikan. Hal inilah yang sering ditemui dalam kegiatan pembelajaran. Padahal, setiap kegiatan pembelajaran harus mengacu pada aspek proses mendapatkan hasil dan juga hasil pembelajaran.

Dalam era teknologi, mengetahui bagaimana untuk mendapatkan dan mengevaluasi informasi dan bagaimana menggunakannya untuk memahami dan memecahkan masalah merupakan prasyarat bagi sebagian besar pekerjaan siswa. Langkah pertama dalam menerapkan pendekatan keterampilan sains dimulai dengan mendefinisikan apa yang akan dilakukan oleh siswa. Kemudian kerja penemuan (discovery work) yang mengatur keterampilan ilmiah ke dalam tiga kelompok terpisah yaitu: keterampilan proses, keterampilan penalaran, dan keterampilan berfikir kritis. Kelompokkelompok ini sesuai dengan tiga jenis keterampilan kognitif yang berbeda. Keterampilan proses digunakan untuk mengumpulkan informasi. Keterampilan penalaran membantu siswa memahami informasi yang mereka kumpulkan dengan mengembangkan pikiran yang terbuka, keingintahuan, logika, dan pendekatan berbasis data untuk memahami dunia. Keterampilan berpikir kritis mengharuskan siswa untuk menerapkan informasi dalam situasi yang baru dan dalam memecahkan masalah (Valentino, 2000 dalam http://rudy-unesa.blogspot. com).

Sains terbentuk dan berkembang melalui suatu proses ilmiah. Dalam pembelajaran sains, proses ilmiah tersebut harus dikembangkan dalam diri siswa sebagai pengalaman yang bermakna. Sains tidak hanya mengutamakan hasil (produk) saja, tetapi proses juga sangat penting dalam membangun pengetahuan siswa. Kenyataan di sekolah berdasarkan pengalaman dan pengamatan penulis, keterampilan proses ini masih sangat kurang atau terkesan diabaikan, sedangkan orientasi pembelajaran masih kepada hasil yang dicapai.

Saat ini terdapat software Tracker yang memungkinkan siswa untuk melakukan penelitian dalam hal kinematika secara komprehensif. Software ini melalui metode analisis video tentang kejadiankejadian alam terutama yang berhubungan dengan kelajuan, kecepatan, percepatan, gaya, medan gravitasi, konversi dan konservasi energi. Melalui software ini diharapkan siswa mampu mengaktifkan keterampilan proses yang dimiliki, melalui observasi yang dilakukaan, pengukuran yang dihasilkan dan dikalibrasikan kedalam software, proses perancangan percobaan dalam analisis video, penginterpretasian data yang dihasilkan berupa grafik dan tabel data hingga pada penarikan kesimpulan berdasarkan data statistik yang dihasilkan proses tracking yang dilakukan siswa dengan software Tracker. Sehingga ketercapaian atau keberhasilan pembelajaran tidak hanya dilihat dari aspek hasil pembelajaran tetapi juga proses untuk mendapatkan hasil tersebut.

Berdasarkan jurnal IOPSCIENCE, yaitu tentang pengkuran percepatan gravitasi bulan berdasarkan video yang dibuat oleh 
NASA, peneliti berfikir untuk mendapatkan nilai percepatan gravitasi bumi. Percobaan ini dapat diintegrasikan kedalam materi gerak jatuh bebas kelas $\mathrm{X}$ SMA. Sebenarnya, percobaan ini adalah standart experiment dalam fisika. Namun dengan menggunakan software ini diharapkan siswa dapat mengoptimalkan keterampilan proses yang dimiliki melalui metode analisis video software Tracker. Pada akhirnya, diharapkan dengan menerapkan percobaan gerak jatuh bebas yang diintegrasikan ke dalam metode analisis video software Tracker, keterampilan proses sains yang dimiliki siswa akan terlatih secara optimal.

Pertimbangan lain yang melatar belakangi peneliti melakukan penelitian ini, berdasarkan wawancara dan observasi yang dilakukan langsung oleh peneliti di SMAN 1 Sooko Mojokerto, kegiatan pembelajaran pada materi pokok gerak jatuh bebas yang dilakukan di SMAN 1 Sooko Mojokerto sejauh ini hanya dilakukan dengan memberikan demonstrasi peristiwa jatuh bebas oleh guru dan siswa menerima secara langsung tanpa melalui proses percobaan atau penemuan hasil/konsep. Secara umum di dalam pembelajaran fisika, kegiatan percobaan dibedakan dengan kegiatan pembelajaran sehari-hari dikelas. Guru hanya memberikan kegiatan percobaan dalam waktu tertentu dan tidak terintegrasi ke dalam kegiatan pembelajaran. Penilaian pada kegiatan percobaan pun hanya berfokus kepada aspek psychomotor siswa saja dan belum menyentuh keterampilan proses siswa secara khusus. Penilaian untuk keterampilan proses sains siswa tidak dilakukan dan memang tidak menjadi suatu prioritas. Jadi, orientasi yang dilakukan masih kepada hasil dan belum menyentuh proses.

Berdasarkan uraian diatas, penulis ingin menerapkan metode analisis video dengan software Tracker di dalam pembelajaran fisika untuk materi gerak jatuh bebas kemudian mendeskripsikan keterampilan proses yang dimiliki oleh siswa kelas X SMAN 1 Sooko Mojokerto.

Berdasarkan pengamatan dan wawancara peneliti di SMAN I Sooko Mojokerto dalam pembelajaran fisika, percobaan dibedakan dengan kegiatan pembelajaran sehari-hari dikelas. Guru hanya memberikan kegiatan percobaan dalam waktu tertentu dan tidak terintegrasi ke dalam kegiatan pembelajaran. Penilaian pada kegiatan percobaan pun hanya berfokus kepada aspek psychomotor siswa saja dan belum menyentuh keterampilan sains siswa secara khusus. Hal ini berdampak kepada keterampilan proses sains yang dimiliki siswa. Dari uraian tersebut penelitian ini adalah:

1. Bagaimanakah keterlaksanaan pembelajaran dengan metode analisis video software Tracker pada konsep gerak jatuh bebas?

2. Bagaimanakah keterampilan proses sains siswa setelah menerapkan metode analisis video software Tracker di dalam pembelajaraan fisika konsep gerak jatuh bebas?

3. Bagaimanakah aktivitas siswa dalam pelaksanaan pembelajaran dengan metode analisis video software Tracker?

4. Bagaimanakah respon siswa dalam pelaksanaan pembelajaran dengan metode analisis video software Tracker?

5. Kendala apa saja yang ditemukan saat menerapkan metode analisis video software Tracker?

Berdasarkan uraian rumusan masalah di atas, tujuan penelitian adalah:

1. Mendeskripsikan keterlaksanaan pembelajaran dengan metode analisis video software Tracker pada konsep gerak jatuh bebas.

2. Mendeskripsikan keterampilan proses sains yang dimiliki siswa setelah menerapkan metode analisis video software Tracker di dalam pembelajaraan fisika konsep gerak jatuh bebas. 
3. Mendeskripsikan aktivitas siswa dalam pelaksanaan pembelajaran dengan metode analisis video software Tracker.

4. Mendeskripsikan respon siswa dalam pelaksanaan pembelajaran dengan metode analisis video software Tracker.

5. Mendeskripsikan kendala-kendala yang ditemukan saat menerapkan metode analisis video software Tracker.

Berdasarkan latar belakang masalah di atas, penelitian dibatasi pada objek penelitian, materi pokok yang diajarkan, aspek yang dinilai yaitu kognitif proses, dan keterampilan proses yang diamati yaitu:

1. Subjek penelitian ini adalah siswa kelas X Sekolah Menengah Atas (SMA) Negeri 1 Sooko Mojokerto.

2. Materi yang diajarkan adalah konsep gerak jatuh bebas dan pengukuran nilai percepatan gravitasi bumi.

3. Sangat banyaknya jenis keterampilan proses sains, sehingga peneliti tidak dapat mencakup seluruh keterampilan proses sains yang hendak diamati. Keterampilan proses yang akan diamati dibatasi pada:
a. Mengamati/observasi
b. Mengukur
c. Merancang eksperimen
d. Interpretasi data
e. Komunikasi

4. Aspek yang akan dideskripsikan adalah keterlaksanaan pembelajaran melalui lembar pengamatan pengelolaan kelas, keterampilan proses siswa melalui soal uji keterampilan proses, aktivitas siswa melalui penilaian kinerja, respon siswa melalui angket respon siswa, dan kendala-kendala yang ditemukan saat menerapkan metode analisis video software Tracker.

\section{METODE PENELITIAN}

Jenis dari penelitian ini adalah deskriptif kuantitatif dengan one group pretest posttest design. Desain ini termasuk dalam jenis pre-experimental desain. Penelitian ini dilaksanakan di SMA Negeri 1 Sooko Mojokerto dimulai pada tanggal 24 April 2012 dan berakhir pada 4 mei 2012 semester genap tahun ajaran 2011/2012. Subjek penelitian ini adalah siswa kelas X SMA Negeri 1 Sooko Mojokerto yang terdiri dari 2 (dua) kelas Bilingual. Cara menentukan sampel adalah dengan menggunakan teknik sampling peluang atau sampling acak yaitu simple random sampling. Desain eksperimennya adalah sebagai berikut :

\begin{tabular}{|l|l|l|l|}
\hline $\mathrm{R}$ & $\mathrm{O}_{1}$ & $\mathrm{X}$ & $\mathrm{O}_{2}$ \\
\hline $\mathrm{R}$ & $\mathrm{O}_{1}$ & $\mathrm{X}$ & $\mathrm{O}_{2}$ \\
\hline
\end{tabular}

Keterangan :

$\mathrm{R}=$ Sample yang diambil secara acak

$\mathrm{X}=$ Metode analisis video dengan software Tracker

$\mathrm{O}_{1}=$ Kelas sebelum diberi perlakuan. Kelas ini diuji awal dengan soal yang berintegrasi dengan keterampilan proses.

$\mathrm{O}_{2}=$ Kelas setelah diberi perlakuan metode analisis video dengan software Tracker, diukur keterampilan proses siswa, mulai tahap awal hingga akhir dengan rubrik yang sama ketika uji awal dan diberikan soal yang berintegrasi dengan keterampilan proses.

Penjelasan mengenai prosedur penelitian yang dilakukan adalah sebagai berikut:

Dalam design ini dipilih dua kelas bilingual secara random. Satu kelas sebagai kelas eksperimen 1 dan kelas yang lain sebagai kelas replikasi dengan nama kelas eksperimen 2. Langkah selanjutnya peneliti mengamati keterampilan proses siswa dengan cara memberikan soal uji keterampilan proses: mengamati, mengukur, merancang eksperimen, interpretasi data, dan komunikasi. Langkah berikutnya, siswa dilatihkan metode analisis video dengan software Tracker yang sangat berguna meningkatkan keterampilan proses siswa, kemudian siswa melakukan percobaan berdasarkan petunjuk LKS. Siswa melakukan percobaan sesuai dengan rancangan yang mereka lakukan dan dengan panduan LKS yang telah 
dibagikan. Siswa merekam percobaan yang dilakukan dengan kamera digital dan menganalisis video yang dibuat dengan software Tracker. Pada tahap ini guru mengobservasi kinerja siswa berdasarkan rubrik penilaian kinerja yang telah dibuat. Tahap berikutnya dilakukan tes untuk mengetahui peningkatan keterampilan proses siswa setelah menerapkan metode analisis video software Tracker.

Instrument yang digunakan adalah sebagai berikut:

1. Silabus

2. Rencana Pelaksanaan Pembelajaran (RPP)

2. Lembar Kerja Siswa (LKS)

3. Lembar pengamatan pengelolaan pembelajaran.

4. Rubrik penilaian kinerja

5. Soal-soal untuk menguji keterampilan proses.

6. Angket respon siswa

\section{HASIL DAN PEMBAHASAN}

Berdasarkan uji soal keterampilan proses yang dilalui yaitu taraf kesukaran, daya beda, reliabilitas, dan validitas, dihasilkan sejumlah butir soal keterampilan proses yang valid dan reliable. Soal-soal inilah yang akan digunakan untuk menguji keterampilan proses siswa setelah menerapkan metode analisis video software Tracker di dalam proses pembelajaran.

Hasil penelitian ini berupa keterlaksanaan pembelajaran, hasil uji keterampilan proses siswa, aktivitas siswa saat pembelajaran, respon dari siswa, dan pengamataan kendala-kendala selama penerapan metode analisis video software Tracker. Berikut ini akan dibahas lebih mendalam tiap hasil yang didapatkan dari penelitian yang telah dilakukan.

\section{Deskripsi keterlaksanaan pembelajaran}

Secara umum keterlaksanaan kegiatan pembelajaran dengan metode analisis video software Tracker di kelas X-5 dan X6 SMAN 1 Sooko Mojokerto berdasarkan lembar pengamatan pengelolaan kelas sangat bagus dan memuaskan. Persiapan guru sebelum mengajar mendapatkan penilaian 4 (sangat baik). Nilai yang didapatkan pada kegiatan awal, inti, dan penutup adalah 3 (baik) dan 4 (sangat baik). Teknik bertanya guru mendapatkan nilai 3 (baik), suasana kelas (antusias guru dan siswa) mendapatkan nilai 4 (sangat baik). Berdasarkan penilaian tersebut dapat dikatakan bahwa kegiatan pembelajaran fisika konsep gerak jatuh bebas dengan metode analisis video software Tracker terlaksana dengan baik.

\section{Hasil uji keterampilan proses siswa}

Berdasarkan hasil uji keterampilan proses yang diberikan, siswa yang telah dilatihkan keterampilan proses melalui metode analisis video software Tracker mengalami peningkatan keterampilan proses yang dimiliki. Hal ini selaras dengan hasil penelitian yang menyatakan bahwa model pembelajaran berbasis keterampilan proses sains secara signifikan efektif untuk meningkatkan kemampuan proses sains siswa (Hariyono:2006) dimana termasuk di dalamnya pelibatan teknologi juga turut mempengaruhi keterampilan proses siswa. Dalam hal ini metode analisis video software Tracker melalui pelatihan keterampilan proses yang ada di dalamnya juga mampu meningkatkan keterampilan proses siswa. Berikut ini hasil uji keterampilan proses beserta pembahasan pada saat pre tes dan post tes dari masingmasing subjek penelitian:

Berdasarkan nilai pre tes dan pos tes siswa kelas X-5 dan X-6, diketahui nilai siswa mengalami peningkatan pada saat pos tes dibandingkan pada saat pre tes. Pada saat pre tes siswa kurang baik dalam mengerjakan soal keterampilan proses karena tidak didukung secara maksimal dengan keterampilan proses yang dimiliki siswa dalam hal mengamati, mengukur, merancang eksperimen, interpretasi data, dan komunikasi. Setelah siswa kelas X-5 menerapkan pembelajaran fisika konsep 
gerak jatuh bebas dengan metode analisis video software Tracker dimana didalamnya turut dilatihkan keterampilan proses siswa dalam hal mengamati, mengukur, merancang eksperimen, interpretasi data, dan komunikasi, nilai tes keterampilan proses siswa mengalami kenaikan yang signifikan pada saat pos tes dengan uji soal keterampilan proses. Berikut ini ketuntasan hasil belajar siswa pada saat diberikan uji keterampilan proses ditampilkan dalam bentuk grafik.

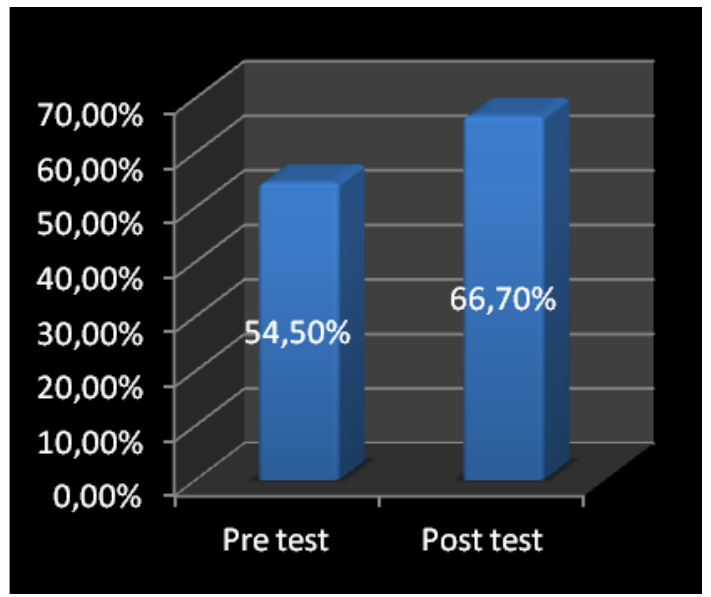

Grafik 1. Ketuntasan hasil belajar kelas X-5

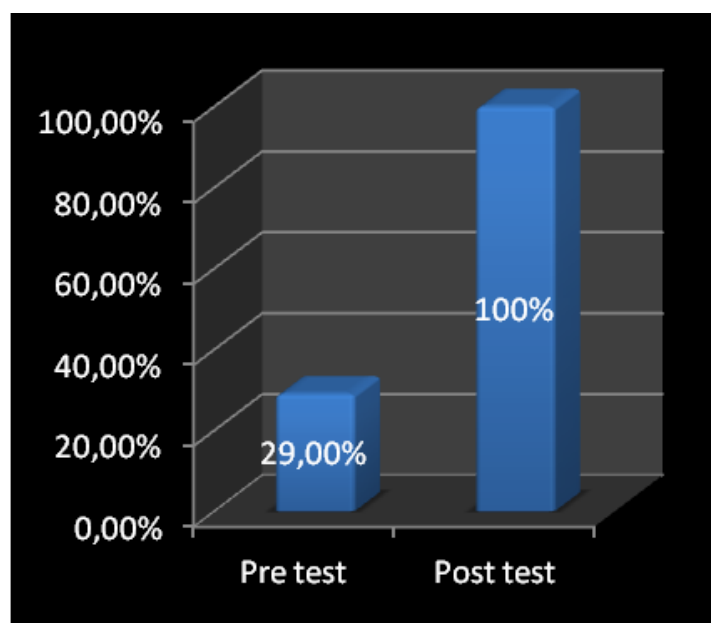

Grafik 2. Ketuntasan hasil belajar kelas X-6

\section{Deskripsi aktifitas siswa}

Aktivitas siswa selama kegiatan pembelajaran sangat aktif. Mereka sangat antusias dengan metode analisis video software Tracker. Hal ini terlihat mulai dari tahap motivasi, dimana video yang ditampilkan guru mampu menarik keingintahuan siswa tentang gerak jatuh bebas sehingga membuat siswa sangat aktif pada saat kegiatan inti yaitu menganalisis video gerak jatuh bebas dengan software Tracker. Keaktifan siswa sangat terlihat mulai dari proses install software, membuat video, mengkalibrasi ukuran sebenarnya, tracking, hingga menghasilkan data tool dan dilanjutkan presentasi kelompok. Hal ini disebabkan karena software Tracker ini tergolong baru untuk diterapkan di dalam pembelajaran fisika. Sehingga siswa merasa sangat tertarik dan ingin mengetahui software yang dapat diaplikasikan ke dalam berbagai percobaan fisika yang berbasis mekanika ini. Keaktifan siswa terlihat di dua kelas yang menjadi subjek penelitian yakni X-5 dan X-6.

\section{Deskripsi respon siswa}

Berdasarkan angket respon siswa, tanggapan siswa sangat baik terhadap software Tracker. Mereka tertarik karena memang metode ini baru mereka temui sehingga mereka merasa ingin tahu tentang keunggulan dan cara kerjanya. Hal ini sangat terlihat pada saat kegiatan pembelajaran dimana siswa sangat antusias dengan kegiatan percobaan gerak jatuh bebas dan menganalisisnya dengan metode analisis video software Tracker.

\section{Deskripsi kendala saat menerapkan metode analisis video software tracker.}

Beberapa kendala saat menerapkan analisis video software Tracker diantaranya adalah:

\section{a. Program yang tidak compatible}

Saat proses install ada beberapa laptop milik siswa yang sangat sulit untuk diinstall software Tracker. Karena ada beberapa laptop siswa yang tidak memiliki program java atau ada program yang tidak compatible dengan software Tracker. Beberapa cara mengatasinya adalah dengan mengisntallkan terlebih dahulu program java kedalam laptop siswa atau uninstall program yang tidak bisa bekerja bersama dengan software Tracker. Berdasarkan pengalaman kami, program 
yang tidak compatible misalnya adalah smartsound yaitu salah satu sistem program dari Power Director (program pengolah video semacam moviemaker).

b. Jumlah laptop yang dimiliki siswa.

Pada saat penelitian yang kami lakukan, hanya ada beberapa laptop yang dibawa siswa. Sehingga peneliti hanya bisa membagi kelas kedalam 5 kelompok. Namun hal ini sangat terbantu dengan kelengkapan kelas yang sangat memadai seperti diantara ketersediaan LCD (Liquid Crystal Display), layar display, dan audio yang memadai.

c. Kualitas video yang dianalisis

Kualitas video yang dianalisis bergantung pada resolusi alat perekam yang digunakan untuk membuat video (http://weelookang.blogspot.com/2011/1 1 tracker-sharing-to-moehqofficers.html). Video yang dibuat siswa rata-rata memiliki frame yang rendah, hanya sekitar 10 frame/s. Sedangkan untuk mendapatkan hasil analisis yang baik minimal diperlukan 25 frame/s. Sehingga peneliti juga harus menyiapkan video dengan kriteria minimal tersebut sebagai pembanding untuk dianalisis.

\section{SIMPULAN DAN SARAN}

Berdasarkan analisis deskriptif keterlaksanaan pembelajaran, keterampilan proses siswa setelah menerapkan metode analisis video software Tracker, aktivitas siswa, respon siswa, dan kendala-kendala yang muncul, peneliti menyimpulkan beberapa hal berikut:

1. Keterlaksaan pembelajaran fisika dengan metode analisis video software Tracker sangat baik.

2. Keterampilan proses siswa dalam hal mengamati, mengukur, merancang eksperimen, interpretasi data, dan berkomunikasi mengalami kenaikan baik secara kualitas maupun kuantitas. Secara kuantitas terlihat dari peningkatan jumlah siswa yang tuntas dalam mengerjakan soal keterampilan proses. Secara kualitas adalah peningkatan skor rata-rata tiap kelas pada saat pos tes dibandingkan hasil pre tes.

3. Aktivitas siswa berdasarkan penilaian kinerja juga sangat baik.

4. Respon siswa berdasarkan angket juga baik.

Beberapa saran peneliti tentang penggunaan metode analisis video software Tracker adalah sebagai berikut:

1. Metode analisis video software Tracker ini, dapat diaplikasikan ke dalam berbagai macam percobaan fisika yang berbasis mekanika. Sehingga metode ini sangat dimungkinkan untuk meningkatkan keterampilan proses siswa melalui kegiatan eksperimen yang dilakukan. Selain konsep gerak jatuh bebas, masih banyak lagi konsep fisika yang bisa diintegrasikan kedalam software ini. Misalnya: gerak parabola, bandul fisis, gerak benda di bidang miring, dan lain sebagainya.

2. Keterampilan proses yang sangat banyak jenisnya tidak memungkinkan untuk diteliti secara keseluruhan di dalam penelitian ini. Oleh karena itu, peneliti menyarankan bagi peneliti lain yang ingin mendalami metode ini untuk diaplikasikan ke dalam pembelajaran fisika untuk meneliti keterampilan proses selain mengamati, mengukur, merancang eksperimen, interpretasi data, dan berkomunikasi.

3. Software Tracker memiliki akurasi yang sangat tinggi untuk menentukan percepatan gravitasi (g) bumi karena cara tracking yang dilakukan dapat menggunakan 2 cara yaitu manual maupun otomatis. Oleh karena itu, bagi peneliti lain yang ingin meneliti dari sisi kontens materi dapat memperdalamnya dengan membuat video percobaan yang lebih baik dengan menggunakan kamera beresolusi tinggi.

\section{DAFTAR PUSTAKA}

Arikunto, Suharsimi 2003. Dasar-Dasar Evaluasi Pendidikan (Edisi Revisi). Jakarta: Bumi aksara. 
Carin, Arthur A.1993.Teaching Science Through Discovery.Professor Emiritus Queens College.

Depdiknas.2006.Standar Kompetensi dan Kompetensi Dasar SMA/MA. Jakarta: Depdiknas.

Giancoli, Douglas C.2001. Fisika Edisi Kelima Jilid I. Jakarta: Erlangga.

Hariyono.2006. Model Pembelajaran Berbasis Peningkatan Keterampilan Proses Sains. JURNAL PENDIDIKAN DASAR VOL.7.UNESS

Ibrahim, Muslimin.2003.Asesmen Berkelanjutan. Surabaya: Unipress UNESA.

Nur, Mohammad.2011.Modul Keterampilan-Keterampilan Proses Sains. Surabaya: Unipress UNESA.
Sudirman N,dkk.1987.Ilmu Pendidikan. Bandung: Remaja Rosda Karya.

Sugiyono.2009. Metode Penelitian Pendidikan. Bandung: Alfabeta.

Surapranata, Sumarna.2004.Analisis, Validitas, dan Reliabilitas Interpretasi Hasil Tes. Bandung: Remaja Rosda Karya

IOPSCIENCE.2011.Videos determine the Moon's g. Phys. Educ. 4612

(http://rudyunesa.blogspot.com/2012/01/pembel ajaran-berbasis keterampilan.html)

(http://iopscience.iop.org/00319120/46/1/F01)

(http://weelookang.blogspot.com/2011/1 $1 /$ tracker-sharing-to-moehqofficers.html) 